\title{
How to identify bud initiation and count needle primordia in first-year spruce seedlings
}

\author{
C.W.G. Templeton, K.D. Odlum and S.J. Colombo
}

\begin{abstract}
Bud initiation and subsequent bud development are key steps in the nursery production of first-year temperate spruce seedlings for reforestation. An understanding of the bud initiation and development processes and monitoring methods are of vital importance to both tree seedling nursery workers and foresters. A review of bud morphology and the bud development process is given for spruce seedlings. The equipment required and techniques used in the determination of bud initiation, and estimation of the number of needle primordia are presented. When properly applied, the examination of spruce buds forms a cornerstone for successful nursery management using extended greenhouse culture.
\end{abstract}

Key words: bud initiation, bud morphology, bud dissection, black spruce, Picea mariana, needle primordia, nursery management

\section{Introduction}

Forestry practices in temperate regions are influenced by the regular punctuation of the active growth of conifers by periods of dormancy. The onset of dormancy is marked by numerous physiological and morphological changes within the tree. One morphological development is the initiation and formation of buds. Bud initiation and development are closely linked to dormancy, frost hardiness, and stress resistance in tree seedlings. An understanding of the bud initiation and development process and monitoring methods are, therefore, of importance to both tree seedling nursery workers and foresters.

Bud initiation is a key step in the nursery production of first-year seedlings for reforestation and can be diagnostic of the cessation of shoot growth and the commencement of winter hardening. Bud initiation in greenhouse production of container seedlings to be overwintered outside must occur within a set time span if seedlings are to develop sufficient levels of shoot frost hardiness before exposure to low temperatures (Colombo et al. 1989). For successful overwintering, consideration must also be given to other factors, such as the development of frost hardiness of the root system. The Extended Greenhouse Culture hardening regime for spruce seedlings has been developed to maximize winter hardiness within an acceptable time frame and it relies upon the dissection of buds as an operational tool for assessing seedling condition (Colombo et al. 1982, 1984). If bud development is still underway when trees are moved outside for overwintering, large losses of seedlings in the nursery may occur (Colombo 1984). Those seedlings which do

Ontario Forest Research Institute, P.O. Box 969, 1235 Queen St. E., Sault Ste. Marie, Ontario, Canada P6A 5N5.
L'amorce des bourgeons et le développement subséquent de bourgeons constituent des étapes déterminantes dans la production en pépinière de semis d'un an d'épinette de climat tempéré destinés au reboisement. La compréhension de l'amorce des bourgeons et des processus de développement en plus des méthodes de suivis sont de prime importance à la fois pour les employés de pépinières forestières et pour les forestiers. Cet article comprend une révision de la morphologie des bourgeons des semis d'épinettes et de leur processus de développement. L'équipement requis et les techniques utilisées pour déterminer l'amorce des bourgeons, ainsi que l'estimation du nombre d'aiguilles du primordium sont présentés. Adéquatement appliqué, l'examen des bourgeons d'épinette constitue la pierre angulaire du succès de la gestion d'une pépinière utilisant un mode de production prolongée sous serres.

Mots clés: amorce des bourgeons, morphologie des bourgeons, dissection des bourgeons, épinette noire, Picea mariana, primordium des aiquilles, gestion d'une pépinière survive may be damaged or of inferior quality resulting in reduced plantation performance in the critical establishment years (Colombo 1982, Vanhinsburg and Colombo 1990).

Shoot growth potential may be promoted by increasing the number of needle primordia in the terminal bud during greenhouse production. Spruce buds contain a finite amount of preformed growth on a "telescoped" embryonic shoot, which will expand with the resumption of growth the following spring. Increased shoot growth potential of container seedlings may be achieved by providing environmental conditions during bud development which favour the initiation of needle primordia (Colombo 1986). Seedlings with large numbers of needle primordia in buds have a superior potential for height growth in favourable post-planting conditions (Colombo 1986, Pollard 1974, Ununger and Kang 1988), and rapid height growth is a major contributor to the successful establishment of new plantations, especially where competing vegetation may overtop planted seedlings. In addition, plantations established during the summer using seedlings which have initiated terminal buds are more stress resistant and better able to withstand harsh climatic conditions (Koppenaal and Colombo 1988).

This paper describes procedures for dissecting buds and for assessing bud development in first-year spruce seedlings. The procedures described are also suitable for buds of older spruce seedlings and trees, and also for buds of related genera (e.g. Abies, Pseudotsuga) with minor modifications. This information is intended as a management tool to be used by field foresters, forestry technicians and managers of tree seedling nurseries.

\section{Equipment Required}

In order to dissect and examine conifer buds, a stereoscopic dissecting microscope equipped with supplemental 

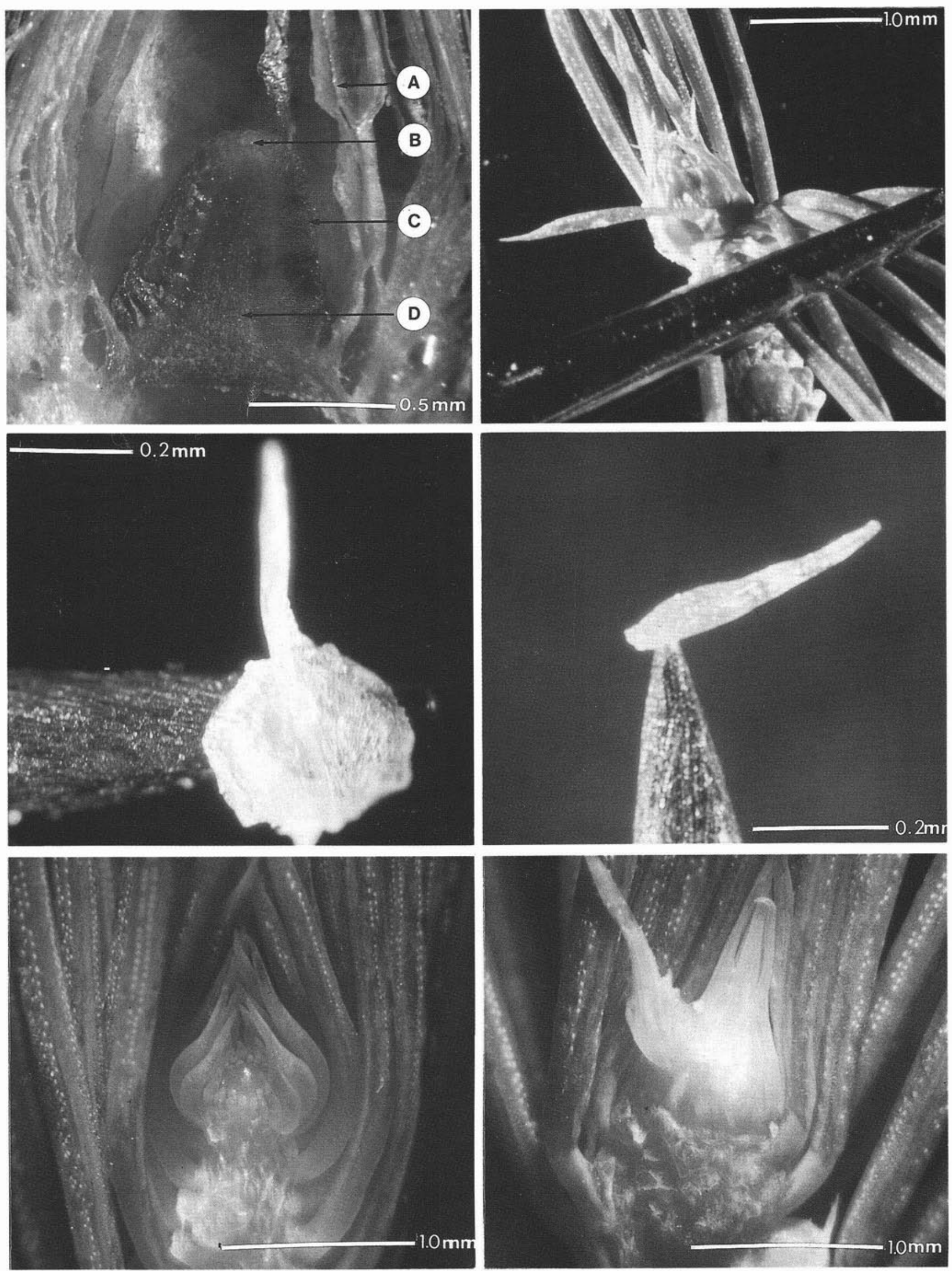
lighting is required. The dissecting microscope selected should have a magnification range of about $10 \times$ to $40 \times$. Fibre optic lighting provides cool light and the greatest flexibility for lighting the subject. However, adequate incandescent light sources are available at much lower cost. A pair of micro-dissecting forceps having extremely fine tips is also required for the detailed work necessary for bud dissection.

\section{Bud Morphology}

Bud dissection is aided by an understanding of basic bud morphology. A dormant spruce bud is composed of two main parts: the embryonic shoot, which will form a large part or all of the following year's new shoot, and the bud scales (Fig. 1). The embryonic shoot is composed of a central pith, around which is a ring of vascular traces, each associated with a needle primordium, an outer layer of cortex, and, at the tip, a shoot apical meristem. The apical meristem is the location of new cell formation in a shoot: all the cells within a shoot trace their lineage back to one of the original mother cells in the apical meristem (Gregory and Romberger 1972, Young and Hanover 1977).

Removal of the bud scales allows the embryonic shoot to be observed. Bud scales are attached to the stem below the base of the embryonic shoot. In our experience, terminal buds of 1-year-old spruce seedlings contain 20-30 bud scales. Detailed descriptions of bud development and the related scientific terminology have been given by several authors (Romberger 1963, Cutter 1971, Young and Hanover 1977).

\section{Bud Initiation}

Two forms of growth occur in northern spruce species: predetermined growth (also called preformed growth) and free or neoformed growth (Pollard and Logan 1974, Halle et al. 1978, Colombo 1986, von Wuhlisch and Muhs 1987). In predetermined growth, needle primordia and their associated stem internodes, present in the dormant bud, expand during the growing season. In free growth, needles and their associated stem internodes expand during the growing season shortly after they have been initiated. Free growth occurs in seedlings from the time of germination until the formation of the first terminal bud, and may also occur in subsequent growth periods. In some spruce species, trees up to 10 years of age may undergo a period of free growth (Jablanczy 1971, Pollard and Logan 1974).

Recently initiated bud scales can be distinguished from recently initiated needles as bud scales are more triangular, translucent, and have less pigmentation. Distinguishing the last-formed needles from the first few bud scales initiated can be difficult. However, bud scales can usually be easily detected within 7-10 days after a bud-initiation stimulus is received (Colombo et al. 1989, Odlum and Colombo 1989).

\section{Figures 1-6.}

Fig. 1. Longitudinal section through a spruce bud. A, Bud scales, B, apical meristem; C, needle primordium; D, pith. Fig. 2. Removal of needles from a spruce shoot using forceps to expose the terminal bud. Fig. 3. A spruce bud primordium destined to become a bud scale, as indicated by the cupped shape, wide base, and pale colour. Fig. 4. A spruce bud primordium destined to become a needle, as indicated by the narrow base and green colour. Fig. 5. A spruce shoot tip in free growth and lacking bud scales. Fig. 6. A spruce shoot tip with recently initiated bud scales.
As bud scales grow and differentiate they become flatter, wider, and whitish. Mature outer bud scales may become brown and have serrated margins, while inner ones remain white. Bud-scale production in 1-year-old seedlings usually ceases 7-10 days after a bud-initiation stimulus is received.

Once bud scale initiation is complete, the apical meristem begins initiating needle primordia. As needle primordium initiation begins, the apical meristem enlarges and may evolve an elongated, conical shape (Cannell and Cahalan 1979). Such an increase in apical meristem size allows a more rapid rate of needle primordium initiation. A rapid rate of needle primordium initiation is maintained for 3-4 weeks, after which primordium formation slows (Colombo et al. 1984) and the size of the apical meristem declines (Cannell and Cahalan 1979).

\section{Procedures for Dissecting Shoot Tips Examination of Shoot Tips for Bud Initiation}

To examine a shoot for terminal bud initiation, the terminal $3 \mathrm{~cm}$ of the shoot should be excised from the tree. The excised shoot should be held in one hand and observed at a magnification of about $10 \times$ using a dissecting microscope. A steady and effective grip can be obtained by holding the shoot between the thumb and index finger. Resting the hand on the stage of the microscope can reduce shake and fatigue.

Needles on the excised stem should be removed to clearly view the shoot tip. Beginning about $2 \mathrm{~cm}$ below the shoot tip, the needles should be carefully plucked from the stem using micro-dissecting forceps. The stem tissue of seedlings in which buds have been newly initiated will not be well-lignified. Therefore, caution must be exercised to avoid tearing the stem apart when removing needles. Needles can be plucked from the stem by grasping three or four needles at a time with the forceps, and pulling them down (away from the shoot tip) until they separate from the stem or by pinching them off at the base using forceps (Fig. 2). Needles should be plucked from the stem in this manner until the only remaining needles are those which are $2-3 \mathrm{~mm}$ long. The remaining expanding needle primordia may be removed from the stem by carefully bending them down and away from the stem. The basal part of these small needles should be examined to determine if the base is widened and flat- to cup-shaped (Figs. 3 and 4). These needles are transitional forms between needles and budscales, and may be green, partially green or may lack pigmentation. The presence of these transitional forms of budscales is indicative of bud initiation if they are clustered around more fullyformed budscales at the shoot apex.

In newly initiated buds, it will be necessary to observe recently initiated primordia found bordering the apical meristem. Such budscale primordia are very small and a magnification of about $40 \times$ may be needed to observe them. They can be distinguished from recently initiated primordia destined to enlarge into needles because budscale primordia are flatter and cup-shaped. Bud initiation can be said to have occurred when any number of bud scales at any stage of development are observed (Figs. 5 and 6).

Dissecting Shoot Tips to Count Needle Primordia

When first learning to count needle primordia, it is advisable to use well-developed buds. Buds which have begun 
growth in the spring are difficult to examine and should be avoided when first learning to count needle primordia. After some experience is obtained examining large mature buds, the investigator may confidently move on to dissect lessdeveloped buds or the smaller buds commonly found on recently bud-initiated seedlings.

As when examining shoots for bud initiation, the terminal $3 \mathrm{~cm}$ of the shoot to be dissected should be removed from the seedling. The needles should be carefully stripped from the upper $2-3 \mathrm{~cm}$ of the stem, as previously described, revealing the bud. When the stem is well-lignified the needles may be plucked by hand.

After the needles have been removed from the shoot, the bud should be viewed under the dissecting microscope at low magnification $(10 \times)$. Using forceps, any stubble left from the needles may be carefully peeled away, along with the outermost layers of the bark so that the bud scales are clearly visible. In well-developed buds with brown bud scales it may be possible to remove a large number of budscales in one step. To do this, an incision should be made using one tip of the forceps to a depth of about $0.5 \mathrm{~mm}$ through the bark at the base of the lower most bud scales (Fig. 7). The tip of the forceps may be used to cut around the entire circumference of the shoot which should loosen the "cap" of bud scales. One tip of the forceps should be inserted under the cap formed by the incision, and the cap lifted off (Fig. 8). If the cap fails to be removed easily, the incision should be made deeper.

Once the cap of bud scales has been removed, a few smaller, white bud scales may remain surrounding the embryonic shoot. These may be removed either by grasping the tissue with the forceps just below the embryonic shoot and pulling the tissue down the stem, or by scraping the tissue off the stem using one tip of the forceps (Fig. 9). In some cases, especially in younger shoots, it will not be possible to remove a cap of bud scales. Under these circumstances, the bud scales should be removed either individually or several at a time by pulling them away from the apex.

\section{Estimation of the Number of Needle Primordia}

Once the bud scales have been removed to reveal the enclosed embryonic shoot the number of needle primordia present can be estimated. When viewed from the side, rows of primordia can be seen spiralling from base to apex of the embryonic shoot of spruce buds (Fig. 10). There are two intersecting sets of rows of needle primordia which spiral in opposite directions, one in a right-handed and one in a left-handed direction. Short rows run more directly up the side of the embryonic shoot, contain fewer primordia, and may spiral in either a left- or right-hand direction. Conversely, long rows contain more needle primordia and spiral more gradually up the side of the embryonic shoot. This spiral arrangement of rows is a common phenomenon in nature. For example, the scales of pine or spruce cones are similarly arranged in spiral rows in the same way as needle primordia are on the vegetative apex.

To count needle primordia the embryonic shoot should be observed from the side at a magnification of 20-30×. Starting at the base of the embryonic shoot, the number of primordia contained within a short row should be counted (Fig. 10). If the embryonic shoot is very large, it may be necessary to rotate the shoot to count all of the primordia in the row. While the estimate of the total number of primordia will be similar whether long or short rows are counted, it is easier and faster to count the number of primordia in short rows. To observe the needle primordia more easily they may be highlighted by first brushing the surface of the embryonic shoot with a water soluble felt tip marker.

To estimate the total number of needle primordia in a bud the primordia in two or three rows should be counted and an average number of primordia per row calculated. Next, the number of rows present should be counted; this may be accomplished by observing the embryonic shoot from the top and counting the number of rows of primordia spiralling out from the apical dome (Fig. 11). Embryonic shoots of first-year seedlings almost always have either 8 long and 13 short rows or 13 long and 21 short rows of primordia. In small buds there may be 5 long and 8 short rows, while larger buds may have 21 long and 34 short rows. It is acceptable and easier to count the number of long rows and to infer from this the number of short rows (e.g. if 8 long rows are counted it can be inferred that there are 13 short rows). The product of the average number of primordia per short row multiplied by the number of short rows equals the total number of primordia within the bud.

\section{Stress Resistance and Bud Initiation}

Forestry professionals involved in reforestation may use information on bud initiation and terminal bud development in planning their operations. Seedlings which have initiated buds have a greater ability to withstand stress, whereas actively growing seedlings are more susceptible to damage. (Koppenaal and Colombo 1988).

Some container seedling nurseries have utilized this information to produce more stress-resistant crops by using artificial short daylengths to induce bud initiation, either in spruce crops overwintered outside which broke bud prior to planting, or in first-year crops sown during the winter for planting during the summer. Artificially induced bud initiation has also been used to increase herbicide-tolerance to allow vegetation control in plantations in the year-of-planting. Forestry professionals who are to receive crops for planting can determine the extent of bud initiation using the techniques described in this paper, and therefore obtain a relative measure of stress resistance.

\footnotetext{
Figures 7-12

Fig. 7. An incision made around the base of a spruce bud using forceps in preparation for removal of the "cap" of bud scales. Fig. 8. A spruce bud from which the "cap" of bud scales has been partially removed. Fig. 9. Removal of bud scales and epidermis to reveal the embryonic shoot in a spruce terminal bud. Fig. 10. An embryonic shoot oriented horizontally to show the number of needle primordia in the short rows. An average of 13 primordia per row are present in the bud shown. Fig. 11. The same spruce embryonic shoot oriented vertically to show the number of short and long rows of needle primordia. There are 34 short and 21 long rows in the bud shown. A total of 442 needle primordia are contained in the bud (13 primordia $\times 34$ rows). Fig. 12. A typical pattern of frost hardiness and bud development for spruce container seedlings in northern Ontario, adapted from Colombo et al. (1984). Index of injury is an expression of the amount of freezing damage. A low index of injury value indicates high frost hardiness.
} 

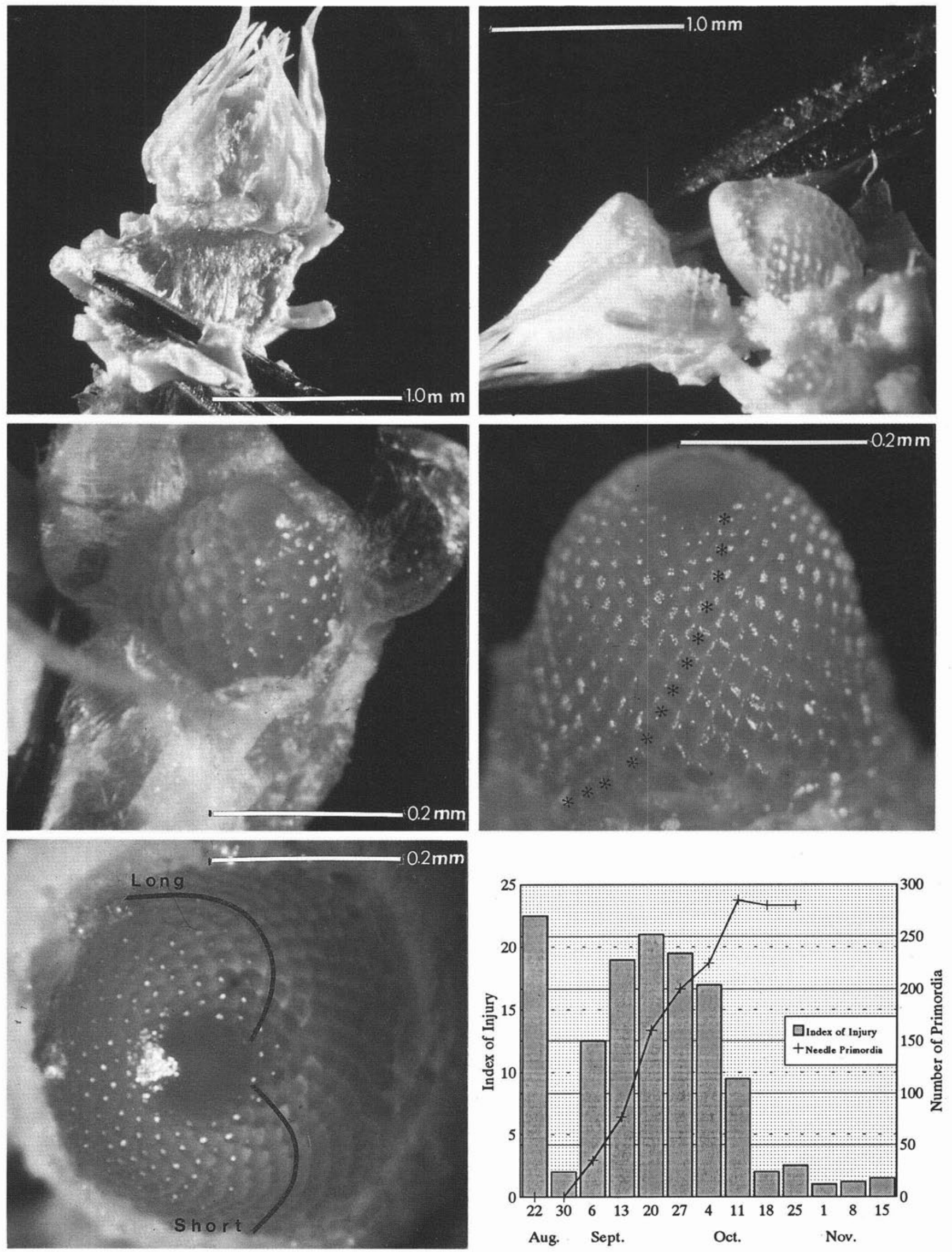
Forestry professionals responsible for reforestation may also be interested in information on numbers of needle primordia in terminal buds as indicators of shoot growth potential and of possible stresses to which crops may have been exposed during nursery culture. Shoot growth potential is positively correlated with the number of needle primordia in terminal buds. However, the absolute amounts of growth will also depend on environmental conditions after planting, since height growth is a function of the number of predetermined primordia, the extension of the internodes between needles and the production of new needles by free growth.

\section{Monitoring Schedule for Overwintering Spruce Container Seedlings}

In container seedlings being prepared for overwintering using the Extended Greenhouse Culture hardening regime (Colombo et al. 1984, 1989), bud dissection may be used to identify the point of $100 \%$ terminal bud initiation in the crop and to determine the average number of needle primordia in terminal buds. Samples should be collected from each greenhouse or seedlot within greenhouses for which bud initiation and development information will be required. Experience has shown that for a uniform crop, a random sample of 20 shoot tips is usually sufficient to obtain a reliable estimate of bud initiation and development. Larger samples or stratified sampling of the crop may be required when significant variation exists in the crop. It is important that seedlings be selected without bias in order to determine the average condition of trees in the crop.

Bud initiation is a key point in the preparation of seedlings for overwintering as it marks the onset of bud dormancy and the beginning of winter hardening. Bud initiation can be expressed as the percentage of sampled shoots having bud scales at their tips (e.g. if 10 of the 20 shoot tips examined show any sign of bud scales, then the crop is said to be $50 \%$ bud initiated). Samples should be taken weekly until 100\% initiation is reached. The time at which $100 \%$ bud initiation is reached is important in preparing container seedlings for overwintering. For example, if artificial short days had been used to induce bud initiation such treatment may be discontinued after $100 \%$ bud initiation is achieved. The point of $100 \%$ bud initiation is also important for predictive purposes as significant increases in frost hardiness will usually occur after a further 4-6 weeks.

Following $100 \%$ bud initiation in the crops, buds may be dissected at weekly intervals to monitor needle primordium formation in the developing terminal buds. A week-by-week comparison of the number of needle primordia being initiated allows nursery managers to indirectly gauge the progress of the hardening process in their crops, since frost hardiness does not greatly increase in first-year spruce seedlings until needle primordium initiation ceases (Colombo et al. 1989, Colombo 1990). For example, first-year spruce seedlings with root collar diameters of about $2 \mathrm{~mm}$ which are hardening under warm temperatures usually do not form more than 250-300 needle primordia in the terminal bud (Colombo and Odlum 1984). As a result, when more than 200 needle primordia are present in the terminal bud and 10 or fewer needle primordia are initiated from one week to the next, it is likely that bud development is nearing completion and the crop will soon develop higher levels of frost hardiness, which will allow it to be moved outside for overwintering. An example of a typical pattern of bud and frost hardiness development is shown in Figure 12.

By regularly monitoring needle primordium initiation nursery managers may also obtain early indications of problems in a crop. Unexpectedly low rates of needle primordium initiation may indicate that seedlings are receiving stressful or sub-optimal conditions, such as waterlogging, drought, low levels of light or low greenhouse temperatures. Once such problems are identified, nursery managers may respond and take remedial action more quickly.

As few as 10 buds can be dissected weekly for each stocklot to be examined for needle primordium initiation. However, as sample size decreases so does the accuracy of the estimate. It is advisable to sample at least 20 buds at the end of the hardening period to more accurately determine the number of needle primordia present in the overwintering terminal buds.

\section{Conclusions}

Bud initiation and subsequent bud development are critical phases of first-year spruce seedling growth which are of practical significance in tree seedling nursery management and reforestation.

The time of bud initiation is important for predictive purposes in preparing crops for overwintering as significant increases in frost hardiness usually occur after a further 4-6 weeks have elapsed. Needle primordium initiation can be followed during bud development to provide an indirect measure of frost hardiness, since freezing tolerance in spruce container seedlings does not greatly increase until needle primordium initiation ceases. Very low numbers of needle primordia in terminal buds may indicate to reforestation professionals that seedlings were exposed to sub-optimal or stressful conditions such as waterlogging, drought, low light intensity or low temperatures during hardening. Such conditions may have adverse effects on seedling vigour and morphology. In addition, seedlings with small buds have lower shoot growth potential. Seedlings which have initiated buds prior to planting will be more resistant to stresses during handling and after planting, and may be able to tolerate late fall applications of herbicide applied in the year of planting. The techniques described in this paper will allow nursery managers and reforestation professionals to determine the status of bud initiation and bud development in spruce seedling crops they are either growing or are responsible for planting.

\section{Acknowledgement}

This paper is the result of a project that was jointly funded by the Governments of Canada and Ontario under the Canada-Ontario Forest Resource Development Agreement (Project No. 33501).

\section{References}

Cannell, M.G.R. and C.M. Cahalan. 1979. Shoot apical meristems of Picea sitchensis seedlings accelerates in growth following bud-set. Ann. Bot. 44: 209-214.

Colombo, S.J. 1982. Winter damage to container seedlings: Consequences and prevention. In Nurserymen's Meeting. Thunder Bay, Ont., June 7-11 1982. OMNR. pp. 10-24. 
Colombo, S.J. 1984. Improving the quality of overwintered container stock using extended greenhouse culture. In Nurserymen's Meeting. Kirkland Lake, Ontario, June 18-21, 1984.

Colombo, S.J. 1986. Second-year shoot development in black spruce Picea mariana (Mill.) B.S.P. container seedlings. Can. J. For. Res. 16: 68-73.

Colombo, S.J. 1990. Bud dormancy status, frost hardiness, shoot moisture content, and readiness of black spruce container seedlings for frozen storage. J. Amer. Soc. Hort. Sci. 115: 302-307.

Colombo, S.J. and K.D. Odlum. 1984. Bud development in the 1982-83 overwintered black spruce container seedling crop. OMNR. For. Res. Note No. 38.4 p.

Colombo, S.J. and Y. Teng. 1992. Seasonal variation in the tissue water relations of Picea glauca. Oecologia (in press).

Colombo, S.J., C. Glerum, and D.P. Webb. 1982. Bud development in black spruce container stock. OMNR For. Res. Note No. 32.5 p.

Colombo, S.J. 1984. Frost hardiness testing: An operational manual for use with extended greenhouse culture. OMNR For. Res. Report No. $110.14 \mathrm{p}$.

Colombo, S.J. 1989. Winter hardening in first-year black spruce (Picea mariana) seedlings. Physiol. Plant. 76: 1-9.

Cutter, E.G. 1971. Plant Anatomy: Experiment and Interpretation, Part 2, Organs. Edward Arnold Publishers Ltd., London, 343 p.

Gregory, R.A. and J.A. Romberger. 1972. The shoot apical ontogeny of the Picea abies seedling: Anatomy, apical dome diameter, and plastochron duration. Am. J. Bot. 59: 587-597.

Halle, F., R.A.A. Oldeman and P.B. Tomlinson. 1978. Tropical trees and forests: An architectural analysis. Berlin, German Federal Republic, Springer-Verlag. 441 p.

Harrison, D.L.S. and J.N. Owens. 1983. Bud development in Picea engelmannii. 1. Vegetative bud development, differentiation, and early development of reproductive buds. Can. J. Bot. 61: 2291-2301.

Jablanczy, A. 1971. Changes due to age in apical development in spruce and fir. Bi-Monthly Research Notes. Can. For. Serv. 27(2): 10.

Koppenaal, R.S. and S.J. Colombo. 1988. Heat tolerance of actively growing, bud-initiated, and dormant black spruce seedlings. Can. J. For. Res. 18: 1103-1105.

Odlum, K.D. and S.J. Colombo. 1989. The influence of night temperature under declining photoperiod on bud initiation in black spruce seedlings. Can. J. For. Res. 19: 274-275.

Owens, J.N. and M. Molder. 1976. Bud development in Sitka spruce. 1. Annual growth cycle of vegetative buds and shoots. Can. J. Bot. 54: 313-325.

Pollard, D.W.F. 1974. Bud morphogenesis of white spruce Picea glauca seedlings in a uniform environment. Can. J. Bot. 52: 1569-1571.

Pollard, D.W.F. and K.T. Logan. 1974. The role of free growth in the differentiation of provenances of black spruce Picea mariana (Mill.) B.S.P. Can. J. For. Res. 4: 308-311.

Romberger, J.A. 1963. Meristems, growth, and development in Woody Plants. USDA For. Serv. Tech. Bull. No 1293. 214 p. Ununger, J. and H. Kang. 1988. Estimated bud development periods in Picea abies. Scand. J. For. Res. 3: 47-53.

Vanhinsberg, N.A. and S.J. Colombo. 1990. Effect of temperature on needle anatomy and transpiration of Picea mariana after bud initiation. Can. J. For. Res. 20: 598-601.

von Wuhlisch, G. and H.J. Muhs. 1987. Effect of spacing on growth especially predetermined and free shoot growth of Norway spruce (Picea abies (L.) Karst.). Silvae Genetica 36: 72-76.

Young, E. and J.W. Hanover. 1977. Development of the shoot apex of blue spruce (Picea pungens). Can. J. For. Res. 7: 614-620.

\section{Membership Dues 1993-1994}

\section{Active Membership}

1st and 2nd year after graduation

(grad 1992, grad 1991) *(\$2.49 G.S.T. inc.)

$\$ 86.00$

Other new members for first year $*(\$ 2.49$ G.S.T. inc.)

Married or equivalent

second member only $*(\$ 2.49$ G.S.T. inc.)

86.00

All other active members $*(\$ 2.49$ G.S.T. inc.)

\section{Other Memberships}

Retired members (to qualify for retired status,

member must have 15 years membership in the

Institute) $*(\$ 2.49$ G.S.T. inc.)

Student Members *(\$1.31 G.S.T. inc.)

Sustaining Individuals (CIF/IFC Members)

Sustaining Corporate $*(\$ 4.98$ G.S.T. inc.)

Upon written application, spousal members of Active Members may have the dues of one reduced by an amount determined annually. Spousal members are members of the same Section who are living together as spouses and using the same mailing address.

The Institute year runs from July 1 to June 30. Applications dated after January 1, 1993 will be charged half dues for that Institute year. Applications dated after April 1st will be charged NO DUES for that Institute year.

Section dues are in addition and range from $\$ \mathbf{5 . 0 0}$ to $\$ 30.00$ per Institute year.

*Note: The portion of membership which covers the cost of the Forestry Chronicle is subject to G.S.T. For tax purposes, this cost is calculated on $\$ 38.00$ which is $\$ 2.49$ G.S.T. (except Student rate of $\$ 20.00 @ \$ 1.31$ G.S.T.) 